\title{
Impact of Teacher Development Programmes on Teachers' Attitudes towards MDG2: the Case of Abeokuta South Local Government
}

\author{
R.O. Oduwaiye ${ }^{1}$, S. Oyeniran ${ }^{1, *}$, Olujimi Olufemi David ${ }^{1}$
}

(C) Uganda Martyrs University

\begin{abstract}
Millennium Development Goal (MDG) 2 focuses on attainment of universal primary education (UPE). Taking cognizance of the fact that attainment of the goal depends heavily on the attitudes and work of teachers involved in the delivery of primary education, this study delved into these teachers' attitudes towards the goal as shaped by their involvement in professional development programmes, taking the case of Abeokuta South Local Government. The findings were that teacher development programmes improve teachers' capacity and disposition towards attainment of MDG2. Pertinent recommendations for theory, policy and practice grounded on this finding are propounded.
\end{abstract}

Keywords $\cdot$ Teacher development programmes $\cdot$ Primary education $\cdot$ MDGs

\section{Introduction}

The Millennium Development Goals (MDGs) originated from the Millennium Declaration produced by the United Nations. The Declaration asserts that every individual has the right to dignity, freedom, equality, a basic standard of living that includes freedom from hunger and violence, and encourages tolerance and solidarity. The MDGs were made to operationalise these ideas by setting targets and indicators for poverty reduction in order to achieve the fundamental human rights set forth in the declaration on a set fifteen - year timeline (Millennium Project, 2005). The MDGs according to Wikipedia (2010) are the eight goals agreed on by 192 countries that are members of the United Nations along with 23 other international organizations. The goals are:

1. Eradicate extreme poverty and hunger

2. Achieve universal primary education

3. Promote gender equality and empower women

4. Reduce child mortality

\footnotetext{
${ }^{1}$ University of Ilorin. *Corresponding author: saheed_oyeniran@yahoo.com.
} 
5. Improve maternal health

6. Combat HIV/AIDS, malaria and other diseases

7. Ensure environmental sustainability

8. Develop a global partnership for development.

A critical look at the goals reveals that they are mutually interrelated in the sense that, the provision of unfettered access to quality education will greatly lead to the realization of goals 1, 3,4,5,6 and 7. Goal 8 stems from the fact that the world is a global village, inter connected and sharing the same fate, this makes it mandatory that bridges of partnership should be across continents in order to eliminate illiteracy, poverty, diseases and inequalities which usually stem from ignorance and poverty, otherwise the world would be hell on earth for all (Millennium project, 2005).

The Federal Government of Nigeria realizes this crucial role of education in creating wealth as well as widening opportunities for individual and stimulating manpower development in the society, that it reiterates in the national philosophy of education that:

1. Education is an instrument for national development, to this end, the formulation of ideas, their integration for national development and the interaction of persons and ideas are all aspects of development,

2. Education fosters the worth and development of the individual, for each individual's sake, and for the general development of the society,

3. Every Nigerian child shall have equal opportunity to education irrespective of any real or imagined disabilities. (Federal Republic of Nigeria, 2004).

But more laudable is the practical step taken by the Federal Government towards realizing these goals by launching the Universal Basic Education in 1999 which aims at providing free, compulsory Universal Basic Education for all Nigerian children for the first nine years of schooling.

In the same vein, to ensure that those who must have dropped out of school as a result of one reason or the other are given another opportunity to acquire literacy and life skills, the UBE included within its ambit adult and non-formal education and to reach the unreached; it equally included the education of nomads and migrant fisher men and women.

However, since teaching demands a continuous development of knowledge and ability, and because primarily, education is rapidly changing and this requires constant effort on the teacher to keep the pace. A dedicated teacher had little or no time to rest on his oars, if he does, he will go down stream. A good teacher considers how he will broaden his knowledge and widen his experience after graduation. Barth (1990), was of the opinion that "nothing in a school has more impact on students in terms of skill development, self competence, or classroom behavior, than the personal and professional growth of the teachers. Okorie (1999), was of the opinion that regardless of an employee pre-service training level there is need for every staff to constantly renew, upgrade and update his/her knowledge, skill and capabilities in order to keep pace with the rapidly changing society. One should not be satisfied with just being a trained teacher. For one to excel in teaching profession, the profession demand that he/she must continue to update his/her knowledge in order to cope with the problems of education as they manifest.

Across the globe, teachers' roles and power of influence cannot be undermined in the successful implementation and sustainability of innovations or national reforms (Albirini, 2004; Baylor \& Ritche, 2002). In the same vein, the level of success in Millennium 
Development Goal 2 is not dependent solely on quality or sophistication of the programme but rather on the teacher's attitude and positive disposition (Deniz, 2007). For quality to be achieved in education sector, teachers must be responsive to the modern teaching demands by getting acquainted with technology use. Since the focus of learning has changed from teacher centered approach to learner-centered.

In the socio cognitive Theory of Bandura (1971), he emphasizes that the self-system of an individual is a dictator of his thoughts, feelings, emotion and readiness to learn. This he says of course is a resultant effect of the inter-play between the self- system and the environment.

Attitudes according to (Francis, katz, \& Jones, 2000) are precursors of behaviours and behavioural intents. Literatures show that some identified factors inhibiting teachers positive disposition towards MDG 2 include experience that is, were they prepared well in their college days (Garland \& Noyes, 2004)? Age that is years in service (Pope- Davis, \& Twing, 1991) attributes of technology that is simplicity of the new technology (Rogers, 1995), external factors that is other professions doing fine (Norhayati, 2000).

Having noted that teacher development programme is essential for the achievement of Millennium Development Goal 2, this research examined the implications of teachers' attitudes at achieving the goal.

\section{Statement of the Problem}

The proper implementation of any curriculum depends on the quality of the teachers (Jegede, 2007). The need to update the knowledge of the basic school teachers who are responsible for the implementation of the basic education curriculum at that level is paramount. The Federal Government of Nigeria recognized this fact as basic school teachers were involved in the Nationwide Millennium Development Goals project (MDGs re-training workshops) since 2006 for development of teaching skills in the four core subject namely English studies, Mathematics, Basic science and Technology and Social Studies including development of instructional materials. Despite huge sums of money expended on education at basic level in terms of physical structure and training/re-training of its workforce the quality of the pupils in reading, writing and speaking at the end of their primary schooling is nothing to ride home with. This study therefore seeks to establish the relationship between teacher development programmes and their attitudes towards the Millennium Development Goal 2. To this end the following questions were raised to guide the study;

1. Does the teachers' development programme improve the character/mind of teachers in schools?

2. Does inadequate training programme bring about negative attitude of professional teachers toward teaching profession?

3. Does good condition of service motivate teachers to put in their best at achieving Millennium Development Goal 2?

\section{Purpose of the Study}

The purpose of this study is to examine teacher development programmes and their attitude towards Millennium Development Goal 2 in Abeokuta South Local Government, Ogun State. In specific terms, the purposes were to:

1. Investigate the training programmes available for the category of teaching staff in primary Schools. 
2. Investigate whether significant relationship exist between Teacher Development Programme and their attitudes towards Millennium Development Goal 2.

3. Give recommendations based on research findings.

\section{Research Hypotheses}

Based on the research questions stated above, the following hypothesis were formulated to guide the study

Ho1: There is no significant relationship between Teacher Development

Programmes and their attitude towards Millennium Development

Goal 2 in Abeokuta South Local Government, Ogun State.

Ho2: There is no significant relationship between in-service training of

Teachers' and their attitude towards Millennium Development Goal 2.

Ho3: There is no significant relationship between re-training of teachers

and their attitude towards Millennium Development Goal 2.

Ho4: There is no significant difference between male and female teachers attitude towards Millennium Development Goal 2.

Ho5: There is no significant relationship between teachers working experience and their attitude towards Millennium Development Goal 2.

\section{Methods}

The sample for this study comprised of 20 public primary schools, which were randomly selected from 45 public primary schools in the local government. Furthermore, 20 headteachers and 20 assistant head teachers were purposively sampled, and 200 classroom teachers were randomly selected across the schools. This therefore makes 240 respondents. The instrument used for data collection was a researcher-designed questionnaire title "Teachers Development Programmes and their Attitude Towards Millennium Development Goal 2 Questionnaire", (TDPAMDGQ). The instrument was validated to ensure its face, content and structural validity. In order to ensure the reliability of the questionnaire, a pilot study involving two-week interval test-retest reliability test was carried out in two public primary schools, which are not part of the sample. The coefficient of reliability was found to be .68 using Pearson Product Moment Correlation Statistic. This coefficient shows that the instrument can measure what it intends to measure. The research instruments used for collection of data were personally administered on the respondents by the researcher who moved from one school to another until all the sample schools were covered. The data collected were analyzed using descriptive and inferential statistics. Descriptive statistics were used to answer the research questions while the Pearson Product Moment Correlation hypotheses and student $\mathrm{T}$ test were also used to test the five hypotheses at 0.05 level of significance. 


\section{Results of Data Analysis}

\section{Teachers' attitude towards Millennium Development Goal 2}

Table 5: Teachers' attitude towards MDG2

\begin{tabular}{|c|c|c|c|c|}
\hline & Agree & $\%$ & Disagree & $\%$ \\
\hline $\begin{array}{l}\text { MDGs project involves interaction with the teachers to } \\
\text { change their approach to teaching from teacher } \\
\text { centered to learner centered. }\end{array}$ & 231 & 96.3 & 9 & 3.7 \\
\hline $\begin{array}{l}\text { MDGs workshop is an intensive professional } \\
\text { development programme. }\end{array}$ & 237 & 98.3 & 3 & 1.7 \\
\hline MDGs workshop should be done every year. & 226 & 92.1 & 14 & 7.9 \\
\hline $\begin{array}{l}\text { MDGs workshop aim at improving the performance of } \\
\text { teachers through the use of instructional materials. }\end{array}$ & 237 & 98.3 & 3 & 1.7 \\
\hline $\begin{array}{l}\text { It is only a good teacher who covers the syllabus } \\
\text { adequately }\end{array}$ & 194 & 80.8 & 46 & 19.2 \\
\hline
\end{tabular}

Table 6: Teachers' opinions on in-service training

\begin{tabular}{lllll}
\hline & Agree & $\%$ & Disagree & $\%$ \\
\hline $\begin{array}{l}\text { I once enjoyed study leave during which I } \\
\text { was temporarily out of service }\end{array}$ & 99 & 41.3 & 141 & 58.8 \\
$\begin{array}{l}\text { It was after my appointment I did my NCE on } \\
\text { part-time basis }\end{array}$ & 155 & 64.6 & 85 & 35.4 \\
$\begin{array}{l}\text { It was after my appointment I did my first } \\
\text { degree on part-time basis }\end{array}$ & 192 & 80 & 48 & 20 \\
$\begin{array}{l}\text { My degree programme on part-time basis is } \\
\text { in progress }\end{array}$ & 115 & 47.9 & 125 & 52.1 \\
$\begin{array}{l}\text { It was after my appointment I did my ACE } \\
\text { (Associateship Certificate in Education) on } \\
\text { part-time basis }\end{array}$ & 85 & 35.5 & 154 & 64.2 \\
\hline
\end{tabular}

Table 7: Teachers' opinions on re-training

\begin{tabular}{|c|c|c|c|c|}
\hline & Agree & $\%$ & Disagree & $\%$ \\
\hline $\begin{array}{l}\text { In the last three years, I had the opportunity } \\
\text { of attending a workshop/seminar in my } \\
\text { subject specialization }\end{array}$ & 193 & 80.4 & 47 & 19.6 \\
\hline $\begin{array}{l}\text { I have once attended a Millennium } \\
\text { Development Goals Workshop }\end{array}$ & 218 & 90.8 & 22 & 9.2 \\
\hline $\begin{array}{l}\text { In the last three years, I have attended at } \\
\text { least a workshop/seminar on teaching skills. }\end{array}$ & 201 & 83.8 & 39 & 16.3 \\
\hline $\begin{array}{l}\text { I was a beneficiary of workshop on computer } \\
\text { literacy for teachers. }\end{array}$ & 106 & 44.2 & 134 & 55.8 \\
\hline $\begin{array}{l}\text { I have benefited from workshops organized } \\
\text { for teachers on social/life skills. }\end{array}$ & 163 & 67.9 & 77 & 32.1 \\
\hline
\end{tabular}




\section{Hypotheses Testing}

Ho1 There is no significant relationship between Teacher Development Programmes and their attitude towards Millennium Development Goal 2 in Abeokuta South Local Government, Ogun State.

Table 8: Teacher development and attitude towards MDG2

\begin{tabular}{lcccclll}
\hline Variable & N & Mean & SD & df & $\begin{array}{l}\text { Calculated r- } \\
\text { value }\end{array}$ & $\begin{array}{l}\text { Critical r- } \\
\text { value }\end{array}$ & Decision \\
\hline $\begin{array}{l}\text { Teacher } \\
\text { Development }\end{array}$ & 240 & 274.3 & 45.404 & 239 & 0.284 & 0.019 & $\begin{array}{l}\text { Reject } \\
\text { Ho1 }\end{array}$ \\
$\begin{array}{l}\text { Programme } \\
\begin{array}{l}\text { Attitude towards } \\
\text { MDG2 }\end{array}\end{array}$ & 240 & 315.8 & 34.690 & & & & \\
\hline r-calculated>critical-r; Ho1 rejected & & & & & & \\
\end{tabular}

$\mathbf{H o}_{2}$ : There is no significant relationship between in-service training of teachers and their attitude towards Millennium Development Goal 2.

Table 9: In-service training and attitude towards MDG2

\begin{tabular}{lllllllll}
\hline Variable & $\mathrm{N}$ & Mean & $\mathrm{SD}$ & $\mathrm{df}$ & $\begin{array}{l}\text { Calculated } \\
\text { r-value }\end{array}$ & $\begin{array}{l}\text { Critical } \\
\text { r-value }\end{array}$ & Decision \\
\hline $\begin{array}{l}\text { In-service training of } \\
\text { teachers }\end{array}$ & 240 & 251.667 & 53.627 & 239 & 0.144 & 0.019 & $\begin{array}{l}\text { Reject } \\
\text { Ho }\end{array}$ \\
$\begin{array}{l}\text { Attitude towards MDG2 } \\
\text { r-calculted>r-critical; Ho2 rejected }\end{array}$ & 315.875 & 34.690 & & & & \\
\hline
\end{tabular}

$\mathbf{H o}_{2}$ : There is no significant relationship between re-training of teachers and their attitude towards Millennium Development Goal 2.

Table 10 Re-training and attitude towards MDG2.

\begin{tabular}{|c|c|c|c|c|c|c|c|c|}
\hline Variable & & $\mathrm{N}$ & Mean & SD & Df & $\begin{array}{l}\text { Calculated } \\
\text { r-value }\end{array}$ & $\begin{array}{l}\text { Critical } \\
\text { r-value }\end{array}$ & Decision \\
\hline $\begin{array}{l}\text { Re-training } \\
\text { teachers }\end{array}$ & of & 240 & 297.0000 & 58.754 & & 0.307 & 0.019 & $\begin{array}{l}\text { Ho is } \\
\text { rejected }\end{array}$ \\
\hline $\begin{array}{l}\text { Attitude } \\
\text { MDG2 }\end{array}$ & towards & 240 & 315.8750 & 34.690 & 239 & & & \\
\hline
\end{tabular}

Ho3: There is no significant difference between male and female teachers attitude towards Millennium Development Goal 2.

Table 11: Difference in Teachers' attitude towards MDG2 by Gender

\begin{tabular}{llllllll}
\hline Variable & $\mathbf{N}$ & Mean & SD & df & $\begin{array}{l}\text { Calculated t- } \\
\text { value }\end{array}$ & $\begin{array}{l}\text { Critical t- } \\
\text { value }\end{array}$ & Decision \\
\hline Male & 39 & 307.949 & 30.965 & & 1.564 & 1.651 & Accept \\
Female & 201 & 317.413 & 35.232 & 239 & & & Ho \\
Total & 240 & & & & & & \\
\hline
\end{tabular}


Ho H $_{\text {: }}$ There is no significant relationship between teachers' working experience and their attitude towards Millennium Development Goal 2.

Table 12: Teachers' working experience and attitude towards MDG2

\begin{tabular}{llllllll}
\hline Variable & N & Mean & SD & Df & $\begin{array}{l}\text { Calculated r- } \\
\text { value }\end{array}$ & $\begin{array}{l}\text { Critical r- } \\
\text { value }\end{array}$ & Decision \\
\hline $\begin{array}{l}\text { Teachers working } \\
\text { experience }\end{array}$ & 240 & - & - & 239 & 0.625 & 0.019 & $\begin{array}{l}\text { Reject } \\
\text { Ho }\end{array}$ \\
$\begin{array}{l}\text { Attitude towards } \\
\text { MDG2 }\end{array}$ & 240 & 315.86 & 34.69 & & & & \\
\hline
\end{tabular}

r-calculated>r-critical; Ho5 rejected

\section{Discussion}

Findings of this study show that teachers have positive attitude towards Millennium Development Goal 2. The teachers considered Millennium Development Goal 2 workshop as a way of improving their general professional well being.

Table 6 shows varying degree of teachers opinion towards in-service training, as most of them went through in-service training using their own hard earned money. This implies that government was not doing much at encouraging them for in-service training. Adeyoju, (1999) opined that skills or attitudes, as a determinant of behaviour and performance can be shaped by new experience often provided by activities included in in-service programmes.

It can be seen that teachers' opinions on re-training of teachers is commendable. This means that many of them were attending re-training programmes through MDG workshops. However, most teachers have not attended computer literacy workshop for teachers. Going by the words of Barth (1990), nothing in a school has more impact on students in terms of skills development, self confidence or classroom behaviour than the personal and professional growth of their teachers. To achieve this, the teachers needs to be continuously developed through re-training programmes.

Alabi (2002), also said that teachers development programmes are activities engaged in by teachers to enhance their knowledge, skills and attitudes in order to educate pupils more effectively. Also Omoregie (2006) is of the opinion that it as a process of gaining experiences to change the serving teachers attitudes, behaviours or opinions. These therefore show the importance of teachers' development programmes in the career growth of teachers in the Local Government. Ijaiya (1991), affirmed that it is not possible to learn everything about teaching while in training and also the advancement in technology has mandated in-service training for teachers to update their knowledge and ensure their professional development for the sake of good teaching and effective pupils learning. And teachers that thirst for knowledge and learning never slacked until death. Therefore, government should try to give adequate opportunities for in-service training in order to update their knowledge in their disciplines. Oyedele (2000) agreed completely with the findings of this study when he recommended that re-training (seminars, workshops, conferences) programmes should be organized for teachers and training packages should be put in place for effective productivity and positive attitude.

Obanya (2006), opined that attending to the yearnings and aspiration of the teachers become imperative for all concerned knowing fully well that the teachers' physical and psychological state, his attitude, feeling and disposition are all crucial to learning 
processes. And that the systematic impoverishment of teachers contribute to over $70 \%$ of the poor quality of education in Nigeria. The social stigma coupled with the various crucial outstanding challenges may not enhance the goal of teaching and ultimately the goal of education. He also affirmed that if we take a closer look at history, developed nations such as the United States of America and Russia place much emphasis on the teaching force so much that teachers form part of the most eminent people in the community. The reason stems from the fact that these teachers produce future leaders of these nations and those who will keep the technological development growing. Industrialized nations are what they are now in terms of economic power, political stability, military strength, technological know-how and sophistication due to the proper recognition given to the teachers. On the other hand, these teachers at various levels of education have been reciprocating this gesture by putting in their best in teaching. Such can be done in this country too and the result will be effective teaching.

Positive attitude as one of the ingredients of greatness in life must be induced in the classroom teachers for them to perform optimally. The right attitude to their work would impact positively on their learners by getting them to appreciate and cultivate good values that can translate to societal greatness. In other words, a teacher must love being a teacher irrespective of gender and experience; it is by loving their job that their best can be tapped in a conducive environment. Therefore, one way at creating positive work attitude for the current crop of Nigerian teachers is through in-service training and re-training programmes to impact right attitudes which would go a long way in bringing success to the Millennium Development Goal 2.

\section{Conclusion}

Based on the findings of the study it is concluded that teachers' development was mostly valued by the teachers and had a major role to play in terms of quality of work. Employee training and development therefore are at the heart of employee utilization, productivity, commitment, motivation and growth. This training could be the systematic development of knowledge, skills and attitudes required by an individual to perform adequately in a given task or job. Therefore teachers re-training should be government priority. Also teachers professional status, esteem, gender and experience has been noted as a strong conditioner for their commitment and performance. These priviledges and the provision of instructional and infrastructural facilities are expected to motivate a tenured staff meet the obligation of their organization including effective teaching.

\section{Recommendation and Implication for Theory and Practice}

The much needed change that is desired in the educational system may be an illusion if there is no paradigm shift from the traditional sit-and-get training sessions or one -timeonly workshops to a well planned, ongoing professionals development programme that is tied to a goal, with built-in evaluation, and sustained by adequate financial outlays. An acceptable and appropriate training strategy rather than the once in a while, un coordinated and management imposed training programmes.

A major problem militating against progress in this area is inadequate funding. This can be overcome if the governments show more commitment by committing more funds to finance teachers' development while a collaborative approach by all stakeholders through 
partnership to fund study grants will help in no measures to provide the much needed financial backing.

An area which needs further attention is that aspect of goal of teachers' development that is connected with change in attitude by participant in teachers development programmes. Training will only enable them acquire knowledge and skills, but will not change their attitude. The only way to change the behavioural patterns as well as attitude of teachers is through motivation. Government will therefore do well by providing adequate compensation as well as improved working conditions for teachers to meet their personal needs.

Teachers Registration Council of Nigeria (TRCN) should be mobilized in helping to develop teachers and to regulate standard in practice.

The Universal Basic Education Scheme (UBE) and other stakeholders in the education enterprises as well as the private sector such as the non-governmental organizations (NGOs) and good spirited individuals, should be maintaining and sustaining basic, qualitative education.

This research work has succeeded in recommending a paradigm shift for teacher development and a frame of reference for future teacher development arrangement for the basic school teachers. It suggested strategies for an effective teacher development arrangement and also recommended a policy framework within which teacher development will thrive. It recommended best practices for institutional arrangement that will make for an efficient and effective teacher development approach for meeting future challenges in teacher development. It is a modest contribution towards redressing the imbalance, inequity and inequality that exist in the teacher development programme for basic school teachers in Nigeria.

\section{References}

Adeyoju, C.A. (1999). Training, value and adjustment among primary and post primary teachers. In J.O. Obemeata, S. O. Ayodele \& M. A. Araromi (Eds.), Evaluation in Africa. Ibadan: Stirling Horden Publishers (Nig.) Ltd.

Alabi, A.T. (2002). School personnel management. In D.O. Durosaro \& S. Ogunsaju (Eds.), The craft of educational management. Ilorin: INDEMAC Print Media.

Albirini, A. (2004). Teachers' attitude toward information and communication technologies: The case of Syrian EFL teachers. Computers \& Education, 47(4), 373398.

Bandura,A. (1971). Psychoteraphy based upon modeling principles. In A.E. Bengua \& S. Garfield (Eds.), Handbook of psychoteraphy and behaviour change. An empirical analysis. New York Wiley and Sons Inc. Retrieved March 17 , 2012 from www.europeanjournalofsocialsciences.com/ejss32.pdf

Barth, R. (1990). Improving school from within: teachers, parents and principals can make the difference. San Francisco: Jossey- Bass. Retrieved November 17 ${ }^{\text {th }}, 2010$ from www.wesoedu.com/knowledge Review 15.

Baylor, A., \& Ritche, D. (2002). What factor facilitate teacher skill, teacher morale, and perceived student learning in technology-using classrooms? Computers \& Education, 39(1), 395-414.

Deniz, L. (2007). Prospective class teachers, computer experience and computer attitude. International Journal of Social Sciences, 2(2), 116-122. 
Federal Republic of Nigeria, (2004). National policy on education. ( $4^{\text {th }}$ edition) Lagos : NERDC.

Francis,L.J., Katz, Y.J., \& Jones, S.H. (2000). The reliability and validity of the Hebrew version of the computer attitude scale. Computers \& Education, 35(2), 149-159.

Garland, K.J., \& Noyes, J.M. (2004). Computer experience: a poor predictor of computer attitudes. Computers in Human Behaviour, 20(6), 823-840.

Ijaiya, N.Y.S. (1991). A guide to supervision of instruction. Ilorin: Grace Graphic re pro. Co.

Jegede, O. (2007). Producing teachers for UBE through open and distance learning. UBE Forum Journal of Basic Education. 2(2), 64-72.

Millenium Project(2005).Investing in development: A practical plan to achieve millennium Development Goals.UK and USA:Earthcsan.

Norhayati, A.M. (2000). Computer technology in Malaysia: Teachers' background characteristics, attitudes and concerns. The Electronic Journal on Information Systems in Developing Countries. Accessed December 15,2008 Retrieved May 1 ${ }^{\text {st }}, 2012$ from http://www.ejisdc.org.

Obanya, P.A.I. (2006). Teaching without teacher. Lagos: AOCOED Lecture series.

Okorie, N.C. (1999). Organizational setting of leadership. Ogoni. Fredsbary Printers and Publishers. Retrieved May 1 ${ }^{\text {st }}, 2012$ from www.wesoedu.com/knowledge Review 15.

Omoregie, N. (2006). Inadequacy in teacher education in Nigeria: the way out. art and education. Retrieved October $14^{\text {th }}, \quad 2011$ from htpp://www.transcampus.org/JORINDV8JUN2010/JournalsV8NO1Ju...

Oyedele, P.K. (2000). Enhancing educational productivity through effective staff personnel administration in Nigeria schools. In E.O. Fagbamiye \& D.O. Durosaro (Eds.), Education and productivity in Nigeria. Ilorin: Haytee press.

Pope-Davis, D.B., \& Twing, J.S. (1991). The effect of age, gender, and experience on measures of attitude regarding computers. Computers in Human Behaviour, 7(4), 333339.

Rogers, E.M. (1995). Diffusion of innovation (4 $4^{\text {th }}$ ed.). New York: The Free Press.

Wikipedia, (2010). Female education. Retrieved March $1^{\text {st }}, 2010$ from http://en.wikipedia.org/wikifemale education. 